\title{
BEYOND SKILLS AND DOCTRINE: THE NEED FOR POLICY SKILLS AND INTERDISCIPLINARITY
}

\author{
Nathan Jon Ross*
}

There is debate about the ratio of doctrine to skills in undergraduate law programmes arising from a purported lack of practice-ready capability. This article looks at this discussion relative to an assumed objective of universities, which is to develop graduates with a rounded understanding of the world, and with skills for objective fact-finding and analysis. Rather than the two dimensions of doctrine and skill, this article employs a framework of four dimensions: basic and deep skills, and basic and deep knowledge. It is used to assess a four-year law programme taught largely through case method against that assumed objective of universities. It concludes that two substantive elements were not addressed sufficiently: policy skills (as an element of deep skills) and deep knowledge. The importance of those elements is described and recommendations are offered for how to incorporate them with minimal impact on the teaching of legal skills and doctrine.

\section{INTRODUCTION (PROBLEM DEFINITION)}

There is an ongoing discussion about the balance in legal education of teaching doctrine and teaching the skills required for practice, including some observations that there is insufficient focus

* Research Fellow in Law, Victoria University of Wellington, Barrister and Solicitor of the High Court of New Zealand, and BEnvSc (Newcastle). The author would like to thank the Rt Hon Sir Geoffrey Palmer QC, Associate Professor Alberto Costi, Wendy J Risely and Elena Mok for discussions and input into developing this article. An earlier version of this article was awarded the 2016 Oxford University Press and Australasian Law Teachers Association Best Legal Education Paper. 
on the latter. ${ }^{1}$ In the United States, for example, a recent assessment by the Illinois Bar Association concluded that: ${ }^{2}$

Law school graduates must be equipped with practice-ready skills to succeed in today's legal marketplace.

It is no longer sufficient for law school graduates to merely think like lawyers; they must be able to perform

the basic tasks central to legal practice.

This dichotomy of skills versus doctrine is an over-simplification of the substance of legal education, and each of those elements are also over-simplified. For example, the push for practiceready skills presumes that at least a majority of graduates will practice and end up in litigation, despite the increasing trend towards alternative forms of dispute resolution, and despite the fact that many graduates employ their qualification in other areas. On the other hand, a heavy reliance on doctrinal teaching may overlook the ever increasing and often amended volumes of statutes and regulations, and the resulting need for greater emphasis on the skills for statutory interpretation.

Whilst acknowledging that legal education is much more than simply skills and doctrine, the focus here is on what else is at stake in a law degree other than graduates' abilities for resolving disputes. As Sir Geoffrey Palmer says, "[1]aw must respond to social and economic changes and provide a framework for future development. Law reform is attached to the idea of progress. ${ }^{3}$ For such reasons, Twining described the idea of: ${ }^{4}$

... the lawyer as Pericles - the law-giver, the enlightened policy-maker, the wise judge [with] intellectual discipline, detachment, breadth of perspective, an interest in human nature and a capacity for independent and critical thought.

Twining is critical of both ideas of lawyer as plumber ("competent technician") $)^{5}$ and lawyer as Pericles, but the latter reveals the essential thesis of this article. Most environmental, social, cultural and economic policy issues are perpetual challenges, and they are enabled by the law. For this reason,

1 For a summary of this ongoing discussion, see John Lande "Reforming Legal Education to Prepare Law Students Optimally for Real-World Practice" [2013] J Disp Resol 1. For a history of the development of legal education in New Zealand, including debates about the balance of legal and non-legal education, see Peter Spiller "The History of New Zealand Legal Education: A Study in Ambivalence" (1993) 4 Legal Education Review 223; and Margaret Wilson and ATH Smith "Fifty Years of Legal Education in New Zealand: 19632013 Where to From Here?" (2013) 25 NZULR 801.

2 Illinois State Bar Association Report and Recommendations of the Special Committee on the Impact of Current Law School Curriculum on the Future of the Practice of Law in Illinois (February 2016) at 6.

3 Geoffrey Palmer "The Law Reform Enterprise: Evaluating the Past and Charting the Future" (2015) 131 LQR 402 at 404. McGechan similarly noted that students needed to understand the contexts of the law and "its practical bearing on the lives of twentieth century New Zealanders": RO McGechan "The Case Method of Teaching Law" (1953) 1(1) VUCLR 9 at 15-16.

4 William Twining "Pericles and the Plumber" (1967) 83 LQR 396 at 398.

5 At 397. 
law graduates should be equipped to play constructive roles in addressing those problems. However, this need is not sufficiently met with a predominance of Langdellian case method teaching, nor increasing lawyering skills. Graduates should, of course, have the essential capabilities, but two other substantive elements are needed. First, they need to understand the natural and human phenomena that intersect with the law; that is, they need the context of the law, which brings its assumptions into light. Secondly, they need to be introduced to the skills and methods of policy-making, and to the respective bodies of knowledge and expertise that other disciplines bring to that process.

In reaching this conclusion, a principal purpose of universities is restated and the orthodox "skills versus doctrine" debate is summarised. Then, instead of skills and doctrine, four broad dimensions of an LLB are posited: basic skills, deep skills, basic knowledge and deep knowledge. These dimensions frame the assessment of a typical four-year New Zealand undergraduate law programme against the purpose of a university. The key findings are, first, that policy-making and interdisciplinarity are essential deep skills that were almost entirely absent. Secondly, deep knowledge was not a systematic objective and so gaps remained. The risks from these gaps are outlined and recommendations are made for how they might be filled in ways that have minimal impact on the space required for teaching the essential skills and doctrine.

Regarding method, the article is not a scientific analysis. It is based only on the first-hand observations of the author, who undertook a four-year undergraduate Bachelor of Laws (LLB) at the Victoria University of Wellington (VUW) in 2011-2014 as a mature-aged student. The author's prior science education and public sector career gave a particular perspective on the programme that ultimately led to the observations documented in this article, and the ideas developed through that period and since. That LLB programme entailed 21 subjects, of which 11 were compulsory and 10 were electives. ${ }^{6}$ Some of the electives are undertaken by a large proportion of the student cohort, such as International Law, Company Law and Commercial Law, whilst others have a more specialist interest, such as Comparative Law and Climate Change and the Law. It is clear, then, that the findings herein are not the result of comprehensive survey and analysis from which generalisations can reasonably be made, and this weakness is duly noted. However, the universality of the Langdellian method (doctrine) and the debate to increase workplace readiness (skills) indicate that the observations herein are likely to have wider relevance, and are offered simply to contribute to ongoing thinking about course and degree content for the 21st century.

\section{THE PURPOSE OF A UNIVERSITY (INTERVENTION LOGIC)}

In the Education Act 1989, the objectives for tertiary education include contributing to the development of cultural and intellectual life, and to the sustainable economic and social development

6 Although Ethics is not deemed compulsory to earn the LLB, it is included as compulsory since it is a requirement for being admitted to the New Zealand Bar. 
of New Zealand. ${ }^{7}$ Building on such ideas, this article has one key assumption, which is that a university's fundamental purpose is to develop graduates with a rounded understanding of the world, and with the skills and yearning for independent and objective fact-finding and analysis. More colloquially, it is to create "citizens of the world" who "know how to think". The assessment of the author's legal education is relative to this purpose. Whilst universities also have to equip graduates with certain basic skills and knowledge relevant to their respective professions, ${ }^{8}$ and universities and academic staff have the freedom to teach and assess courses in the manner they see fit, ${ }^{9}$ creating citizens of the world should not be lost to creating participants in a marketplace.

\section{THE SKILLS DISCUSSION (COUNTERFACTUAL)}

Since this article proposes a different framework for the debate about increasing the skills content of undergraduate law programmes, a summary of those arguments is helpful. Rabkin describes this as being: ${ }^{10}$

... about vocational training on the one hand (how to draft a will or a set of pleadings, keep good accounts and form a company, for example) versus academic training on the other (the theoretical and moral underpinnings of the law, how to analyse critically, how to undertake research, how to understand the world more broadly and the law's role in it).

This skills versus doctrine debate has been the subject of expert reports dating back to at least 1879 and "[t]hese reports and other analyses repeatedly faulted law schools for over-emphasizing instruction in legal doctrine and analysis at the expense of practical legal training". ${ }^{11}$ Those analysts argue for students to be taught a wider range of skills for legal tasks, such as "diagnosing and planning solutions for legal problems, instilling others' confidence, negotiation, fact gathering, drafting legal documents, counseling, obtaining and keeping clients, and managing legal work". ${ }^{12}$ According to Glesner Fines, the reasons behind a dearth in developing practice skills include "a general skepticism about skills instruction" and a perceived need to cover a growing body of law, which she describes as

7 Education Act 1989, s 159AAA.

8 Section 159AAA(1)(c)-159AAA(1)(e).

9 Sections $160-161$.

10 Franny Rabkin "Ill-equipped law graduates 'not ready for practice"' (16 January 2014) Business Day Live <www.bdlive.co.za>; and Peter Brooks "Why Law Students Need the Humanities" (8 May 2016) The Chronicle of Higher Education <www.chronicle.com>.

11 Lande, above $\mathrm{n} 1$, at 4.

12 At 4 
"the curse of coverage". ${ }^{13}$ In New Zealand, the Professional Legal Studies course was instituted "to impart and enhance generic transferrable skills" ${ }^{14}$ to fill a gap in skills training during university. ${ }^{15}$

One outcome of the debate on the ratio of skills to doctrine has been the reinvention (or at least reinvigoration) of apprenticeship-style learning. In particular, clinical legal education aims to teach skills and doctrine simultaneously. ${ }^{16}$ When experiential teaching focuses on stakeholders who are not lawyers, such as Borrows' teaching with indigenous communities, it is apparent that there is a risk that on-the-ground realities are absent in orthodox lecturing and that undergraduate courses are taught within a legal silo. ${ }^{17}$

\section{A RE-FRAMING OF LEGAL EDUCATION'S DIMENSIONS (INDICATORS)}

An assessment of the efficacy of a law programme must be done against certain objectives. The objective being examined is the abovementioned purpose of universities: creating citizens of the world who know how to think. If we translate that to the law school, it is much wider than problem solving for particular clients' particular issues. It means applying the unique skills of a lawyer to tackling wider policy challenges. The reasons for this are discussed later. In general, however, with major issues like climate change, growing social inequality, reduced government transparency, child poverty and so on, a university education fails graduates and society if it is little more than a doctrinal traineeship. It must be about developing deep foundational learning and thinking skills that enable the growth of intellectual modesty and wisdom. In turn, this fosters a culture of understanding, ethics and

13 Barbara Glesner Fines "Out of the Shadows: What Legal Research Instruction Reveals About Incorporating Skills throughout the Curriculum" [2013] J Disp Resol 159 at 161.

14 Andrew Tipping Review of the Professional Legal Studies Course: Report to the New Zealand Council of Legal Education (August 2013) at [3.1].

15 Neil Gold "Report on the reform of professional legal training in New Zealand for the New Zealand Law Society and the Council of Legal Education" (New Zealand Law Society, Wellington, 1987) at 7, cited in Spiller, above n 1 , at 247, n 121.

16 The University of Chicago Law School "Clinic Projects" <www.law.uchicago.edu>; and for a case study, see Becky Beaupre Gillespie "The Hardest Stories to Tell: What an Intense New Clinic Project is Teaching Seven Students About War, Mercy, and the Frailties of the Human Mind" (2016) 62(2) The University of Chicago Law School Record 8. See also Francina Cantatore "Boosting Law Graduate Employability: Using a Pro Bono Teaching Clinic to Facilitate Experiential Learning in Commercial Law Subjects" (2015) 25 Legal Education Review 147; Rachel Spencer and Matthew Atkinson "Towards a Pedagogy of the Integration of Clinical Legal Education within the Law Curriculum: Using De-identified Clinic Files within Tutorial Programs" (2015) 25 Legal Education Review 121; and Andrew Mitchell and others "Education in the Field: A Case Study of Experiential Learning in International Law" (2011) 21 Legal Education Review 69.

17 John Borrows "Learning from the land: indigenous law in context" (lecture, Victoria University of Wellington, 11 February 2016) ["Learning from the land"]; and John Borrows "Outsider Education: Indigenous Law and Land-Based Learning" (2016) 33 Windsor Yearbook of Access to Justice 1 ["Indigenous Law and Land-Based Learning"]. 
progress. These are the types of qualities that engender a rounded understanding of the world and the appetite for knowledge.

To consider the efficacy of the author's LLB programme against these goals, four broad content dimensions are proposed instead of simply "skills versus doctrine". Before setting them out, it is prudent to acknowledge that discussing the content of a law degree under any such broad labelling is reasonably open to criticism. ${ }^{18}$ However, while acknowledging potential weaknesses, a framework remains a helpful tool for assessing whether various objectives are being met.

The framework proposed here includes basic skills and deep skills, which are the training dimensions, plus basic knowledge and deep knowledge, which are the education dimensions. As conceived of here, training is the development of skills and methods required in the various professions of law graduates. Education, on the other hand, is about the world as it is known and understood through natural sciences, humanities and social sciences, including law. These four dimensions - which are applicable to any degree programme targeted at professional careers, such as law, engineering, science, economics and so on - are explained further below.

\section{A Training Dimensions}

For law, basic training entails some of the day-to-day skills, such as researching the law, and drafting opinions and submissions. The development of these skills in the author's LLB programme was primarily a function of a compulsory course, Legal Research, Writing and Mooting. They were reinforced in an elective, Civil Procedure, and in the post-degree Professional Legal Studies course that is run by separate institutions. With few exceptions, other courses were assessed by traditional means of essays and exams.

Deep training, as advanced here, relates to those skills that are more particular to lawyering, such as statutory interpretation, case analysis, dialectic argumentation and "thinking like a lawyer". Some might argue that these skills are part of education because there is an element of knowledge to them. For example, you have to know and understand the rules of statutory interpretation to apply them. However, it is the skill aspect that matters most. Basic knowledge - such as the purposive rule - can sometimes be mostly about developing a skill, albeit a deeper and unique skill - such as statutory interpretation. With the exception of statutory interpretation, these deep skills were a primary focus of the author's LLB programme and were well developed as a result.

The importance of distinguishing these deep skills from basic skills is that it highlights the fact that, although the deep skills mentioned here are more profound and particular to law, they do not increase a graduate's understanding of the world at large. Deep skills, such as thinking like a lawyer,

18 See Twining, above $\mathrm{n} 4$, at $421-422$. 
do not give students a full context for thinking about broad policy issues and laws' roles in enabling or solving them. As such, deep skills remain as part of the apprenticeship; not the education.

\section{B Education Dimensions}

As noted above, education is about developing knowledge and understanding of the world through, amongst other things, the natural sciences and the humanities and social sciences, including law. The difference between education's basic and deep dimensions will be illustrated using an example from a natural science - ecology - and then the concept will be applied to legal education.

In science, basic knowledge includes snippets like "the harlequin gecko (Tukutuku rakiurae) is endemic to Stewart Island". It would also include other, relatively straightforward facts, such as the environmental characteristics that define its ecological niche. Deep knowledge is knowing and understanding what else is going on for the species that results in it being classified as "nationally vulnerable". ${ }^{19}$ This might include its slow reproductive strategy and other evolutionary adaptations to the harsh climate of Stewart Island, the immediately-proximate threats such as pest species, and wider phenomena such as climate change, as well as the compounding relationships between those phenomena. For the practicing conservation biologist, deep knowledge will go further into the relevant local and national policy issues that create or enable these environmental problems, such as what is going on with local land-holders and what is going on with pest management regimes, and how these relate to local policies and plans, and how the latter in turn relate to national legislation. Deep knowledge is understanding the species' biology and ecology in its complete environmental system, and being able to compute and intuit likely outcomes of multiple changes in its physical, regulated habitat. The ability to navigate this clamour of data relies on an education that covered enough factual matters to enable the science graduate to conceptualise and synthesise the "whole" in their minds, and to be able to create a line of sight to workable options. This systems thinking is going much further than straightforward facts about the animal. ${ }^{20}$

How does this idea from ecology translate to an example in law? The law itself is just basic knowledge. The volume of rules does not alter this fact, just as basic knowledge of the vast number of animal, plant and fungi species does not translate into deep knowledge. Deep knowledge is about wider phenomena and interrelationships. It might start with the ability to see interrelationships between various laws, but it must go further. Deep knowledge is knowing and understanding the natural and human phenomena that intersect with the law, and that bring the law's presumptions and impacts into light. For example, when local authorities develop plans to comply with the Resource

19 Rod Hitchmough and others Conservation status of New Zealand reptiles, 2012 (Department of Conservation, New Zealand Threat Classification Series 2, June 2013) at 8.

20 "In a society which accepts the existence of multiple human qualities, intuition occupies its central place. It helps us to act by seizing the swirl of uncertainty of which imagination and civilization are made. It allows us to express the organic nature of our world and our existence in it": John Ralston Saul On Equilibrium (Penguin, Toronto, 2001) at 212. 
Management Act 1991 (RMA) and the Local Government Act 2002, or central governments seek to amend those statutes, are the main actors and decision-makers actually aware of how the legislation intersects with issues like biodiversity conservation? Furthermore, are they aware of the web of issues that affect biodiversity; not just a statute? Since all indicators for biodiversity have worsened since the RMA was enacted, there is clearly a major disjoint between this principal piece of environmental law and scientific reality.

Why are these natural and human phenomena so important to deep knowledge? The laws of statute books are not "made of star stuff" according to certain "laws of nature". ${ }^{21}$ They do not exist in the pure, natural form of the harlequin gecko. Certain legal rules are universal and appear to have a naturalism basis, such as the prohibition of genocide, but these comprise such a miniscule fraction of all the rules in all the treaties, constitutions, statutes, codes, regulations and cases, that it is self-evident that law is a human construct. As such, the myriad of factitious laws may very well be in contradiction with objectively identifiable laws of nature and laws of human nature. This might, of course, be the result of a conscious decision to compromise between competing policy objectives. But it might be borne out of ignorance and be undesirable.

Deep knowledge is understanding how things work at a fundamental level. To put it simplistically, the laws of nature (including human nature) just "are", and that is part of what scientists try to understand. If a population of harlequin gecko can only survive in certain ecological conditions, then that is just the way it is. Change its habitat and the gecko population will migrate, evolve, decline or die out. Humans can, of course, change how rules of nature play out by fiddling with various elements in a natural system. However, the underlying laws of nature remain unchanged: a species has evolved and adapted to a certain ecological niche and if conditions in that niche alter, changes to the species are inevitable.

Deep knowledge would enable the LLB student to understand the broader context and see reality intersect with the law. This reality is not merely a discrete fact pattern, or dozens of fact patterns. It is the bigger picture, drawn by data that is not conjecture and ideology, but withstands peer-review in its own discipline or disciplines. It overcomes the risk of "separat[ing] intellectual inquiry from reality by adopting a relentlessly abstract approach". ${ }^{22}$

It is not being suggested here that LLB graduates should have a comprehensive understanding of all other disciplines. The argument is, however, that they should have enough understanding to know that there are further questions to be asked of experts in the relevant field.

21 Carl Sagan Carl Sagan's Cosmic Connection: An Extraterrestrial Perspective (Cambridge University Press, Cambridge, 1973) at 189-190.

22 John Ralston Saul The Doubter's Companion: A Dictionary of Aggressive Common Sense (Penguin Canada, Toronto, 1994) at 263. 


\section{GAPS (EVIDENCE)}

The following subsections explore how, in the case study of the author's legal education, there were two main gaps relative to the abovementioned purpose of universities. The first was that there was no introduction to basic policy skills that would enable students to "ask the right questions", except in two niche electives. The second gap was that the law was often presented with minimal, if any, contextual data or key policy debates.

\section{A The Training Gap}

It is repeatedly reinforced in legal education that the state holds all the power, and that lawyers and the judiciary are a bulwark against abuse of that power. But arguing in a Plaintiff $v$ Respondent paradigm is not the only means of checking that power. Influencing policy development is central: "Legal analysis is analysis of what the law is; ... . Policy analysis is analysis of what the law should be". 23

In light of his life-long law reform enterprise, Sir Geoffrey Palmer has come to the conclusion that: ${ }^{24}$

Legal analysis and legal reasoning are not enough in the policy world. Lawyers and Judges and their tool

kit are a necessary condition in the world of policy-making, but they are not a sufficient condition. Both

these worlds can learn from each other. ... Lawyers have much to contribute but many other disciplines

are needed.

Three ideas are particularly discernible from this conclusion. The first is the need for "the law reform enterprise". Obviously, in a world with ongoing and systemic problems, reform is a necessary and continual enterprise. Law schools should be facilitating the development of positive players in this enterprise, that is, "citizens of the world" who "know how to think". ${ }^{25}$ Students should be exposed to the key policy debates in each area of the law, and have some non-legal data that gives insight into the directions those debates might head.

Following on from this, the second idea from Sir Geoffrey's conclusion is that lawyers need policy skills: there is a training gap in legal education. To respond to policy challenges: ${ }^{26}$

The concentration has to be on the design of statutes and that raises a whole range of different issues that common law methodology cannot address. How does one decide the policy that will be contained in the

23 Matthew SR Palmer Thinking about Law and Policy: Lessons for Lawyers (Crown Law, December 2006) at [2].

24 Palmer, above n 3, at 413.

25 Martha Nussbaum cited in "Our Interdisciplinary Legacy: The University of Chicago at 125" (2016) 62(2) The University of Chicago Law School Record 24 at 25.

26 Palmer, above n 3, at 413. 
statute? How does one assemble the support to get it passed? How can one demonstrate that what is proposed will be better than what went before?

The policy skill set is broader than is encapsulated in this summary. As Scott and Baehler explain, "[p]ublic sector analysts and advisers require the particular bodies of knowledge and the specific skills and competencies to allow them to deliver high-quality, value-adding advisory services". ${ }^{27}$ In reality, policy advice happens in many varied, often haphazard ways. Its method depends on a wide range of factors including, inter alia, whether it originates from a policy shop (a government ministry, for example) or from a political source. ${ }^{28}$ Regardless, there are certain processes that can improve the rigour of policy development: from the problem definition, intervention logic and counterfactual; to data collection; to the development of options; to the drafting of legislation, if required. On top of these steps, there is thinking about how to ensure policies across government are integrated and complementary. ${ }^{29}$

In New Zealand, at least, the policy process always involves consultation: within a government agency, between agencies, with portfolio Ministers, and with non-government stakeholders, such as Māori, interest groups and the business sector. The consultation process, in particular, is where Sir Geoffrey's third major point, interdisciplinarity, is most obvious. Hence, including policy into legal education would introduce students to the understanding that: ${ }^{30}$

Policy analysis by its nature is multi-disciplinary, interdisciplinary, and pragmatic - good policy design

draws on a wide range of skills and competencies to create new approaches and frameworks as needed

from the raw materials of existing disciplines.

The University of Chicago has recently celebrated its 125th anniversary and the Law School's event was a celebration of its "interdisciplinary legacy". ${ }^{31}$ Faculty staff includes philosophers, historians and economists, and the Law School has a statistics laboratory. By contrast, in the author's LLB, although some courses introduced certain contexts of the law, only two of 21 courses were explicitly multidisciplinary. The Law and Economics elective was taught predominantly by an economist, with support from lawyers. The Climate Change and the Law elective was taught by Sir Geoffrey, who brought his education and hands-on experience in both law and political science, along

27 Claudia Scott and Karen Baehler Adding Value to Policy Analysis and Advice (UNSW Press, Sydney, 2010) at 241 .

28 See Figure 2.2 at 68-69 for a demonstrative and entertaining flow diagram of such a process.

29 See Girol Karacaoglu The New Zealand Treasury's Living Standards Framework - Exploring a Stylised Model (New Zealand Treasury, Working Paper 15/12, August 2015).

30 Scott and Baehler, above n 27, at 23.

31 Edited transcripts of the event are at "Our Interdisciplinary Legacy: The University of Chicago at 125", above n 25 . 
with many guest lecturers: a scientist, an economist, a former diplomat, and national and local government planners and policy analysts.

There are at least four reasons why policy analysis skills are highly valuable for law graduates. First, for those many graduates who go into policy-related careers, the benefits of teaching law through policy and multidisciplinary lenses are clear. Secondly, advocacy is not only about litigation; it is also about influencing national government and local government policy-making. ${ }^{32}$ Thirdly, "[1]egal analysis does often inherently involve policy considerations" and the judiciary relies on counsel and academics to do that work for them. ${ }^{33}$

The fourth reason for teaching policy analysis relates back to the objective of a university. Introducing policy skills would equip graduates with skills that enable them to ask robust, methodical questions about environmental, social, cultural and economic issues. By extension, those skills and their demand for interdisciplinarity should put law in its context. This should highlight the assumptions and values embedded and excluded from the law. It should also show that laws have outcomes, including unintended consequences, which are in fact measurable, but not often understood in any systematic and explicit fashion. The "know how to think" method of policy analysis can and should be another aspect to the deep skills dimension of legal education.

\section{B The Deep Knowledge Gap}

In addition to the deep skills, "citizens of the world" graduates need deep knowledge. If this dimension is given insufficient attention, then students might finish law school with the foundations of a fine trade, but without a rounded education. So, to assess whether a university's purpose was met, the inquiry includes: are LLB students learning about the world in which the law operates? Are students learning about how factual matters influence the development of the law or - for some subjects, such as transgenderism ${ }^{34}$ and climate change ${ }^{35}$ - not? Are they seeing any reason to question

32 See generally Mai Chen Public Law Toolbox (LexisNexis, Wellington, 2012).

33 Palmer, above n 23, at [12].

34 In New Zealand, to alter one's sex on their birth certificate, an applicant must have had medical treatment: Births, Deaths, Marriages, and Relationships Registration Act 1995, s 28(3). This is in spite of the fact that transgender people may not be able to undergo surgery ( see Stuff "Decades-long wait for gender reassignment surgery" (14 May 2016) <www.stuff.co.nz>) or may not wish to (The Human Rights Campaign "Transgender FAQ" <www.hrc.org>). For further discussion, see Emily Blincoe "Sex Markers on Birth Certificates: Replacing the Medical Model with Self-Identification" (2015) 46 VUWLR 57.

35 As with many countries, New Zealand's climate change policy setting is continually criticised for its lack of scientific basis and accountability. See Jan Burck, Franziska Marten and Christoph Bals The Climate Change Performance Index: Results 2016 (GermanWatch, Bonn, December 2015); Eric Frykberg "NZ's climate change target condemned" (13 July 2015) Radio New Zealand <www.radionz.co.nz>; and Jan Wright Emissions Trading Scheme Review 2015/16: Other matters: Submission to the Minister for Climate Change Issues (Parliamentary Commissioner for the Environment, 28 April 2016). 
the assumptions embedded in the law? It was the author's observation that the answer to these questions was, "yes and no, but not in a systematic fashion". Hence, it is argued here that there was a gap in the author's LLB programme of deep knowledge.

This will be illustrated with two examples from courses in the degree undertaken by the author. First, Ethics. When the author undertook this course, it focused on the primary rules governing lawyers' behaviour and relevant cases, and it was taught using a light Socratic method of teaching legal rules. There were readings and discussion in the first week on the meaning of ethics, but it quickly went into duties to the court, duties to clients and so on. As Ethics is compulsory for students intending to be admitted as a barrister and solicitor, this subject should be taught on an assumption that its students will go on to become officers of the court. ${ }^{36}$ As such, ethics as an academic discipline should be treated seriously. Instead, anecdotally, students seemed to treat the course as a necessary interruption to "more important" rules of law, and they were not actively disabused of this idea. Indeed, the reputation of a zero fail rate reassured students that they could be slack and not take it seriously. There were discussions in lectures on whether some behaviour was or was not appropriate for a person to be fit and proper as an officer of the court. However, those discussions were not held in the context of any theories of ethics or philosophical frameworks for contemplating such issues. The course was taught mainly as just another set of rules.

In Property Law, six (of 24) weeks were dedicated to jurisprudence and a number of important concepts were introduced. Central to that was introducing Wesley Hohfeld's bundle of rights theory and Tony Honoré's ownership bundle. There was also an introduction to historical contexts of property law. This was all essential, but a major gap remained. The actual starting premise of property law was never mentioned: the laws of nature. Because of its historical genesis, property law starts with a presumption of protecting individuals' absolute property rights to protect them from the abuse of those in power. From that starting point, means of regulation have developed as problems were identified. In a contemporary context, that starting presumption means that certain legal persons continue to have rights to (for example) undertake activities that directly or inevitably result in the injection of vast amounts of greenhouse gases into the atmosphere. And when attempts are made to curb these activities, it is controversial because of that simplistic starting point of absolute rights and the concomitant right against uncompensated takings, among other things. This is a fundamental flaw. ${ }^{37}$

The teaching of what is or is not property was devoid of the objective data about the elements of nature required to make those objects to which property status is assigned: the sources and sinks of nature. Elements of nature are the primary resources of tangible property, and energy, water and other

36 See "Information Regarding Admission to the Legal Profession in New Zealand" at [1] in Certificate Application Form (New Zealand Degree Holders Only) (Council of Legal Education, Wellington, 15 March 2016) at sch 1.

37 See David Grinlinton and Prue Taylor Nijhoff (eds) Property Rights and Sustainability: The Evolution of Property Rights to Meet Ecological Challenges (Martinus Nijhoff Publishers, Leiden, 2011). 
inputs from nature are essential for converting those materials into value-added products. Natural systems are also used as places for disposing of by-products and wastes: landscapes as landfills, and waterways and the atmosphere as sewage systems. ${ }^{38}$ To talk of property without any understanding of its actual interactions with the natural world does not just leave a gap in students' awareness. It creates a gap. It gives a fundamentally incorrect impression of what property is - an abstract, incorporeal and malleable human construct - and hence the controversy around the simple premise that you should not use property in a way that is as harmful as climate change. The starting presumption was absolute rights, not the laws of nature. Whilst the philosophy of absolute rights is a critically important aspect of the history and contemporary understanding of property law, it was objectively incorrect in terms of the tangible things which embody those rights.

If universities are helping to develop citizens of the world, then the law must be seen in its context, not in isolation. ${ }^{39}$ This was done successfully in some of the undergraduate subjects undertaken by the author, including Climate Change and the Law and the Treaty of Waitangi component of Public Law. The scientific evidence is clear that international and domestic efforts to mitigate climate change have been far from adequate. In that context, it is unsurprising that the lecturer of the Climate Change and the Law course would want students to understand the context and critique major policy responses. For that purpose, lectures were given by a range of non-legal experts, as noted earlier. Following this essential context, the key international agreements, and domestic statutes and cases were taught and concurrently critiqued relative to that initial data. The students, therefore, received much more than a technocratic method for using the law for the benefit of clients.

Whilst the policy issue is an intrinsically interdisciplinary one, the approach in the Climate Change and the Law course is more widely applicable. The ethos was, in effect, that the efficacy of the law was directly related to the objectively-analysed problem and its consequences, the economic and other policy challenges, and the various human and political behaviours. This approach is clearly not unique to this one issue.

Another example where the context was provided was for the Treaty of Waitangi. A good history of the Treaty is told in the case law. ${ }^{40}$ A school-leaver-aged student commented to the author about his frustration that he had not learned that fuller Treaty history at high school. He believed that that gap had left him susceptible to racist views, which he now understood were wrong. This was a prime example of the "citizen of the world" outcome that results from deep education: not just the law, but the law in its wider factual context.

38 This analysis also applies to intangible property, since it too fuels economic activity and consumption of tangible property.

39 See Borrows "Indigenous Law and Land-Based Learning", above n 17.

40 See Matthew SR Palmer The Treaty of Waitangi in New Zealand's Law and Constitution (Victoria University Press, Wellington, 2009). 


\section{DODGING CONTEXT AND ENTRENCHING POSITIONS (RISKS)}

The deep knowledge and systems thinking that good social science, humanities and natural science education facilitates - along with the skills and rigour of their respective methods - are employed to facilitate a thorough understanding of human beings and nature, including intersections between related phenomena. In the LLB programme, the training, basic knowledge, and discussions on right and wrong risk inadvertently serving the opposite ends; they risk entrenching existing views.

During the author's programme, class discussions about the appropriateness of a behaviour or piece of law were often held without any meaningful data of the environmental, social, cultural, historical, economic or ethical phenomena at play. The main data relied upon were the discrete fact patterns and their relevant laws. When the wider context for the law is absent or superficial, discussions on the rights and wrongs happened in the abstract or in a data vacuum. In such situations, it was left to chance as to whether students' ideas really were challenged. What seemed more likely, however, is that they entrenched an existing opinion, bias or prejudice due to psychological phenomena such as confirmation bias. Confirmation bias is: ${ }^{41}$

The tendency to test one's beliefs or conjectures by seeking evidence that might confirm or verify them and to ignore evidence that might disconfirm or refute them. This bias ... helps to maintain prejudices and stereotypes.

In the Socratic model, students are presented with topics as if they are entirely open to debate; as if all rules and legal decisions reflect entirely subjective positions. As such, there is no objective or rigorous mechanism for shaking students out of confirmation bias, irrespective of whether there is established or extensive agreement on something within the topic's relevant discipline. This does not facilitate robust analysis.

Dialectical argumentation is a powerful tool, but it should be distinguished from critical thinking. Critical thinking is driving for more data to get to more facts, to get more intersectional relationships, to get a better understanding of the true nature of an issue or policy solution, thereby challenging personal bias. Employed properly, the Socratic discussion is a powerful tool for sharpening students' wits and developing their equally powerful ability to "think like a lawyer". However, in the lecture environment, the Socratic method was principally about how opinions shift as more hypothetical shifts or nuances are added in fact patterns. Because this was commonly limited to discrete fact patterns, the absence of wider context means that it is not as robust as critical thinking for considering legal policy and efficacy.

Ultimately, whether law students allow themselves to be challenged or whether they entrench their positions, the Langdellian case method and Socratic discussions would have done little on their own

41 Andrew M Colman A Dictionary of Psychology (4th ed, Oxford University Press, Oxford, 2014). 
to educate students about the true nature of the world and human behaviour because of the common absence of objective data and systems thinking.

\section{DELIVERING POLICY AND DEEP KNOWLEDGE DIMENSIONS (OPTIONS AND RECOMMENDATIONS)}

How can the purpose of a university and a law school be achieved whilst meeting other objectives that enhance graduates' career prospects? Since the 1990s, there has been an increasing trend for students to do conjoint and double degrees. ${ }^{42}$ Relying on that trend, however, has two critical problems. First, financially, it imposes substantially more costs and debts than a single degree, and it generates opportunity costs, insofar as law graduates lose another two years or so from their working life. Secondly, it leaves to chance whether graduates can effectively critique the law's role in responding to policy challenges, rather than seizing the opportunity to ensure that ability at the time the law is taught.

Looking inwardly at the law degree, then, an option for enabling "Lawyer as Pericles and Plumber" is place-based or experiential learning. Maranville argues that experiential learning has the potential to expose students to four types of context in legal education: the people in cases that students read and their real-life circumstances; the institutions and practices that give rise to disputes; the institutions and processes in which doctrine is applied; and the tasks lawyers perform and how doctrine is integral to those tasks. ${ }^{43}$ Mitchell and others have demonstrated benefits from an experiential approach for international law, where students visit relevant organisations and meet with practitioners. ${ }^{44}$ Particularly in relation to indigenous issues, Borrows' practice of teaching law outside of the classroom and in the field offers an even wider context and evidences the potential of broader contextual comprehension. ${ }^{45}$ When students learn from indigenous people on site, they have the opportunity to enhance their knowledge and understanding of different sources of laws and norms: from nature, culture, genealogy and language. Borrows argues that a more profound understanding of these contexts has a legal practice benefit, which perhaps has ethical implications for the practitioner as well.

These various experiential methods have many advantages for student learning and experience. However, in relation to deep knowledge and policy skills, a weakness of experiential learning is that, with some exceptions, it is still relative to discrete fact patterns. Wider context may be discussed by the various actors, but it might be objectively incorrect and, in any event, its provision may be left to

42 Spiller, above $\mathrm{n} 1$.

43 Deborah A Maranville "Infusing Passion and Context into the Traditional Curriculum through Experiential Learning" (2001) $51 \mathrm{~J}$ Leg Ed 51 at 56-57.

44 Mitchell and others, above n 16

45 Borrows "Learning from the land", above n 17; and Borrows "Indigenous Law and Land-Based Learning", above $\mathrm{n} 17$. 
serendipity rather than course planning. Borrows' method offers a more comprehensive contextual experience, but the fullness of context that indigenous people can offer would rarely be available from people in other areas of law and policy.

The experiential and place-based methods are also labour-intensive, so the issue remains as to how to impart context and policy without adding yet more pressures to academics. An obvious reality is that the full environmental, social, cultural or economic field on which each area of law rests simply cannot be accommodated within any degree. Such a "Bachelor of Polymathy" model of teaching law would inflame Glesner Fines' idea of "the curse of coverage". ${ }^{46}$ It is, however, possible to develop graduates' abilities to question the assumptions underlying the law with relatively minor changes to course content.

A second option, then, is using a framework such as that suggested here - basic skills, deep skills (including policy skills), basic knowledge and deep knowledge - as a guide to designing course content. The starting point is introducing the deep knowledge aspect: providing the key non-law information about the general topic, and a summary of the top one or two current policy debates in the area. It should be intentional that this information is not from lawyers, but rather from experts in other disciplines that are more directly engaged with the big picture. Relevant government agencies, non-government organisations and industry bodies often have research and analyses that offer starting points. Two-to-three readings is all that is necessary to introduce this deep knowledge component. Readings should be selected on the basis that they define the problem, and they tackle the most common and controversial policy questions relating to the topic. Although there is some effort and input from the teacher to identify appropriate readings and to teach relative to them in the first week of lectures, the demands are not extensive. It will often be complementary to other contexts given, such as the historical development of the area of law.

This data content can lead into the policy skills element. Include one short reading on policy method in course materials and have a single PowerPoint slide in an early lecture that sets out common policy questions. What is the problem definition? Was the law solving the right problem? How do we know; what was the evidence? What other disciplines would offer expertise? What is the intervention logic? What is the counterfactual? What were the main competing policy objectives and how should they be weighed up against each other? What alternative options were available? Does the law create unintended consequences that ought to be avoided?

After including the contextual data and such policy questions, a course could largely be taught as it is now, except for using the policy questions for occasional reflections on the efficacy of the law. This might also be reinforced in assessments, with some portion of overall grading given to one or more policy questions. Elective courses could dedicate a greater portion of teaching time to expanding the deep knowledge and policy skills content. This was done in the Climate Change and the Law

46 Glesner Fines, above n 13, at 161. 
subject, where the final exam asked whether a carbon tax was more or less attractive than an emissions trading scheme.

A third and more substantial suggestion would be to develop a separate elective on policy-making for law graduates. A dedicated course could explore the policy-making framework in greater depth and then look at specific roles for lawyers. Take an area of law known by the teacher to be weak and explore, first, the wider policy issue, then, secondly, the legal responses to that issue, and then, thirdly, the non-legal responses. To illustrate this with an example indicated at footnote 34 above, issues for transgender New Zealanders, the wider policy issue is that trans people feel excluded from society. This has serious adverse effects on mental and physical health. What law reforms can help? For example, the law might be reformed to make it easier to correct their gender identity on birth certificates and to prohibit discrimination on the basis of gender as well as sex. What about non-law policy responses? The class can explore other matters that are more operational than legislative, such as macro social education and access to appropriate health care.

Following an exercise of this nature (delivered over a number of weeks), the course could take a regulatory reform case study. Take, for example, a council's draft Regional Policy Statement, developed under the RMA. The class can identify and explore a particular policy issue within that draft document and develop a policy and law-based submission. Finally, so that law graduates who go into policy careers have a particular skill to add to a policy unit, the course could include certain skills in translating policy into legislation, to assist parliamentary counsel who draft Bills.

These examples are used simply to illustrate how such a course could be designed and delivered. By going through case studies in policy development and regulatory and legislative reform, students would develop an understanding of such processes, which develops the deep skill set. By researching the topics, perhaps with the input of guest lecturers, students would learn the need for an interdisciplinary approach to problem solving and develop their deep knowledge. These outcomes would be beneficial to students as both citizens of the world and participants in a marketplace. They may also improve the focus of graduate and postgraduate research projects.

A legal education must cover basic and deep skills and basic knowledge. The argument here, though, is that students should be exposed to enough data and enough policy skills to know that there is much more to the law than their opinions, and those of their lecturers and textbook authors. By using a concept like deep knowledge, lecturers might help students to develop the intellectual abilities needed to identify and answer policy questions, to cut through opinion and speculation, to criticise productively, to assess - based on real and objective data - what really matters for individuals and society, and to think creatively and constructively to help solve people's and communities' problems. The aim should be to foster a desire to find out more, and know the always complex and almost always elusive "right answer". This is creating a worldlier citizen than someone who knows the rules and how to use and argue them. 


\section{CONCLUSION}

Nussbaum has reflected that: $:^{47}$

Our society is not perfect, to put it mildly. Nor are its laws perfect. Lawyers should not just be instruments of the status quo, obeying its norms without reflection. ... They should be independent and critical participants, who work to shape a future that is better than the past.

And it is more than just being independent and critical. It is delving into the data - a tumultuous sea of truths, half-truths and everything but the truth - and having the yearning and capability of going beyond opinion and ideology. It is about enabling graduates to have more than a conjecture about what is a "better" future, but understanding that there are objective and analytical measures. As Bertrand Russell said: ${ }^{48}$

The fact is you cannot be intelligent merely by choosing your opinions. The intelligent [person] is not the [person] who holds such-and-such views but the [person] who has sound reasons for what [they believe] and yet does not believe it dogmatically.

Whether the LLB undertaken by the author delivered on a university's traditional role of developing graduates with a rounded understanding of the world was largely left to chance. Graduates need to be equipped to see the difference between evidence-based policy and policy-based evidence. The question remains then as to whether, each year, students are completing the LLB with a fine trade but an untapped capacity to learn. Are law graduates going into the world keen and able to contribute to solutions from an objective, fact-based and ethical starting point? Or are they looking at social and ecological problems with firm opinions that lack an objective comprehension?

Obviously there is a wide range of competing demands on law degrees, and their courses and teachers. Some may argue that teaching students deep knowledge is the role of other faculties, but that confirms Saul's observation that a university is "[a] place in which civilization's knowledge is divided up into exclusive territories." 49 If we are taking a wider perspective about graduates' various roles in society, LLB programmes are doing them a disservice if they choose not to dedicate a small amount of time up front to contextual data and a small amount of time to do some policy thinking about the law and its wider context.

47 Nussbaum, above n 25, at 26.

48 Bertrand Russell Mortals and Others: Volume II: American Essays 1931-1935 (Routledge, London, 1998) at 58.

49 Saul, above n 22, at 301. 